\title{
21 \\ DOUBLE TAXATION CONVENTIONS AS POTENTIAL TOOLS TO PROMOTE CROSS-BORDER PHILANTHROPIC PAYMENTS
}

\author{
Xavier Oberson
}

\section{The problem}

Cross-border payments for philanthropic purposes raise various legal and notably tax concerns. Indeed, domestic laws of the states involved may characterize these payments in various ways and could apply different or even conflicting tax rules. In addition to the exception of the jurisprudence of the EU Court of Justice (EUCJ), which has introduced limits to the potential restrictions or discriminations caused by domestic taxation rules of EU Member States, taxation rules applicable to non-profit organizations are not coordinated. As a consequence, as we will demonstrate further, the risks of multiple or even contradictory taxation consequences of crossborder philanthropic payments could hinder their development and contradict their purposes, which, in essence, are not for profit.

In general, we can summarize the typical domestic tax problems as follows. First, often, states will treat resident and non-resident philanthropic entities differently. As a consequence, frequently, payments for philanthropic purposes in favor of a charitable entity sited abroad will not be allowed as a deduction in the payer's country. Conversely, the country of the recipient entity may also subject payments from foreign sources to profit (or income) tax. Second, resident philanthropic organizations often bear the burden of taxes levied in the source state, typically in a form of a withholding tax, on income received (dividends, interests, royalties and sometimes pensions). Third, the rules of inheritance and gift taxes are usually very different from one state to another. It follows that cross-border charitable inheritances or gifts may potentially be subject to heavy gift or inheritance taxes either in the residence country of the donor (or the deceased person), in the country of the beneficiary or even, in some cases, in the country of situs of specific assets (typically real estate or art collections).

This chapter will therefore try to analyze the extent to which the application of double taxation conventions (DTCs) could solve or at least alleviate the potential tax burden on crossborder philanthropic payments. To that aim, after a brief overview of the main domestic rules of some states in this area (hereafter II.), we will summarize the interesting jurisprudence of the EUCJ, which has developed a rather favorable tax perspective for cross-border charitable 
giving, including for non-EU third countries (hereafter III.). Finally, we will show how existing DTCs, or some new provisions of those legal instruments, may serve as tools to avoid excessive tax burden on cross-border philanthropic payments, alleviate potential double taxation or even create an incentive in favor of transnational charitable giving (hereafter IV.).

\section{Overview of the main domestic tax problems}

\section{A Direct taxes}

\section{Introduction}

Without going into the details of the various domestic tax rules on cross-border payments, we will summarize the traditional tax issues that could arise in a typical cross-border transaction involving a donor (or a deceased person), a philanthropic entity, and beneficiaries, all sited in different states. ${ }^{1}$ For the purpose of our analysis, we will focus on philanthropic entities, namely legal structures (typically an association or a foundation) with a non-for-profit purpose. ${ }^{2}$ In this context, a first distinction should be drawn between the position of the beneficiary and the donor.

\section{The philanthropic entity as beneficiary}

In general, the entity beneficiary of the payments, will be a foundation, an association or a trust ${ }^{3}$. In most countries, foundations or associations, as legal persons, will be subject to domestic profit tax. To the extent they benefit from an exemption based on their philanthropic purpose, these entities would however usually not be subject to profit tax ${ }^{4}$. In general, this exemption should apply both for domestic and international payments, but the state of residence of the entity could apply different domestic rules based on the place of residence of the donor. In particular, it may be more difficult for the host state of the charitable entity to ascertain that a payment from abroad qualifies as a gift, that is, as a payment without any counterpart expected from the donee.

In addition, the conditions of a tax-exempt status are quite different between states and are governed by domestic law rules. For example, under Swiss law, foundations or associations which pursue charitable goals, characterized more generally as "public utility purpose" ("but d'utilité publique"), are exempted from profit and capital tax on payments exclusively and irrevocably affected to the charitable goals. ${ }^{5}$ The concept of a public utility purpose corresponds to an altruistic activity, which serves the public good exclusively and directly. ${ }^{6}$ Philanthropic entities should pursue a goal that benefits the collectivity as a whole and reach that objective based on disinterested sacrifices from their members. ${ }^{7}$ In practice, tax exemption is granted by the competent tax authority under four cumulative conditions: ${ }^{8}$ (i) the pursuit of a goal of general interest; (ii) the members, and notably board members, should follow a disinterested purpose; (iii) the philanthropic activity should be effectively pursued; (iv) the funds are irrevocably attributed to such activity. In practice, qualifying philanthropic activities are usually regarded as meeting the public utility test, namely a charitable, humanitarian, sanitary, ecological, educational, scientific or cultural purpose. The circle of beneficiaries should be opened and undetermined. However, the place of the activity is not relevant. Both domestic or foreign activities are eligible, to the extent that they meet the four conditions mentioned previously. In addition, once the conditions are met, a tax-exempt entity is not taxable on all payments received, notwithstanding their source. As a consequence, charitable payments stemming from Switzerland or abroad, including for gifts or inheritance purposes, will not be subject to profit tax. In other words, 
from the perspective of the beneficiary entity, Swiss domestic tax law does not make any difference between local- or foreign-source payments.

In the United States, in order to obtain a tax-exempt status, the qualifying organization must apply for recognition of the exemption and has to fulfill several requirements, notably to be organized and operated exclusively for the philanthropic purposes mentioned in the law. ${ }^{9}$

\section{Tax position of the donor or payer}

The situation is quite different from the perspective of the payer who makes a payment or a gift to a non-resident philanthropic entity. In most states, subject, however, to specific limits, the payer may deduct charitable payments to a tax-exempt entity resident in that state from income tax. ${ }^{10}$ For example, under Swiss law, charitable gifts in favor of Swiss resident tax-exempt philanthropic entities are deductible, but the scope of the deduction is limited to $20 \%$ of the net taxable income for federal purposes. This percentage varies from canton to canton, but in most cases, cantonal law applies the same limitation as federal law.

However, payments in favor of non-resident philanthropic entitles are either not deductible or subject to complex limitations. ${ }^{11}$ While some states, like Switzerland ${ }^{12}$ and Australia, tend in principle not to grant any deduction for cross-border gifts, other states, like the United States, have a more favorable policy, subject to strict conditions, notably that the gift must be made to a qualifying organization. ${ }^{13}$ Other states also allow for the deduction of cross-border charitable gifts but subject to specific requirements, such as, inter alia, the recognition of the foreign entity as a charitable entity following philanthropic purposes or some geographical limitations on the performance of the charitable activities. ${ }^{14}$ In France, gifts to foreign non-profit organizations are in principle not deductible, but the tax administration may allow such deductions to the extent there is a reciprocal regime between France and the state of the beneficiary. ${ }^{15}$

Some international networks, however, exist, usually of private law nature, such as Transnational Giving Europe (TGE), ${ }^{16}$ which allows, under specific conditions, a deduction of domestic charitable payments, which are then transferred to non-resident beneficiaries. The deduction is subject to strict conditions, and a fee is levied by the intermediate entity in order to cover, notably, the administrative costs of the "cash pool charity." ${ }^{17}$ There are other exceptions based on domestic law.

This uncoordinated approach may result in a non-deduction from payments to a non-resident charitable entity and, in rare cases, in an additional taxation in the country of the recipient entity. Such consequences are generally the result of an absence of recognition of the philanthropic status of a non-resident charitable entity by the state of residence of the donor. Indeed, the conditions of the tax-exempt status are closely related to domestic rules. States may have quite divergent views on which activities may "deserve" a tax-exempt status. In other words, a charitable activity may be regarded as a "public utility activity" in one country and non-philanthropic in another. As we will see, however, within the EU, discriminations between resident and non-resident comparable public entities have been challenged by the case law of the EUCJ (see infra III.). In addition, the compatibility of such differences of treatment with the principle of non-discrimination anchored in DTCs similar to the OECD Model DTCs still needs to be addressed (see infra IV.).

\section{B Inheritance or gift tax}

In this area, domestic tax rules are in general completely uncoordinated and highly dependent upon local peculiarities. ${ }^{18}$ In addition, even if an OECD Model of DTC for inheritance and gift 
tax purposes has been drafted, ${ }^{19}$ there exist very few DTCs in this domain. ${ }^{20}$ In order to demonstrate the potential disparities in the tax treatment of cross-border charitable inheritance or gifts, we may draw a distinction between the state of the payer and the state of the beneficiaries.

In most cases, countries will treat charitable payments to resident or non-resident beneficiary entities differently. In some countries, like Switzerland, we may even find different rules from one canton to the other. Indeed, under Swiss law, the ability to tax gifts or inheritances belong exclusively to the cantons. ${ }^{21}$ It could even occur that charitable gifts or inheritance in favor of entities sited in other cantons could not benefit from a tax exemption available in the canton of residence of the payer. A fortiori, gifts or inheritances from a resident in one canton in favor of philanthropic entities abroad would, in most cases, be subject to a cantonal gift or inheritance tax at the highest cantonal rates applicable to unrelated parties. There are a few rare exceptions. For example, under Geneva law, a total or partial exemption for gifts of inheritance in favor of legal entities abroad may be granted, upon request, by a decision of the Geneva government. ${ }^{22}$ In practice, this decision is difficult to obtain. The canton of Basel-City also seems to grant an exemption for inheritance or gifts of public utility entities, independently from their place of residence. ${ }^{23}$ In addition, there are, under Swiss law, a limited number of intercantonal or international agreements based on the principle of reciprocity. ${ }^{24}$

Since the rules are completely uncoordinated, we could even be confronted with an additional gift or inheritance tax in the country of the recipient.

\section{Consequences}

As a consequence, domestic law does not provide for appropriate solutions to the numerous tax obstacles of cross-border philanthropic payments. First, gifts paid in favor of nonresident philanthropic entities may not benefit from any deduction. Second, in the state of the beneficiary, there is even a potential risk that such payment could be subject to income or profit tax. Third, cross-border gifts and inheritance will often be subject to gifts or inheritance tax, potentially to the maximum applicable third-party rate, in the state of the payer and also, in some cases, even in the state of the beneficiary.

\section{The EU Law}

\section{A The EUCJ case law}

The issue of potential excessive taxation of cross-border charitable payments has, however, been alleviated within the EU. In very interesting jurisprudence, illustrated notably by four landmark cases, the EUCJ has developed a framework which sets coordinated rules for crossborder charitable payments (including gifts or inheritance), notably on the basis of the freedom of movement of capital. ${ }^{25}$

In Stauffer, a musicology center operating as a tax-exempt foundation in Italy received rental income for a building it owned in Germany. This country refused to grant a tax exemption with respect to rental income on the grounds that the beneficiary did not reside in Germany. The EUCJ held that such discrimination was not justified, being contrary to the principle of free movement of capital. ${ }^{26}$ That conclusion was based on the following motivation. First, the court ruled that the principle of freedom of establishment could not be invoked. In order to do so, the enterprise should have secured a permanent presence in the host Member State in which the real estate owned was actively managed. In the present case, the foundation did not have any premises in Germany for the purposes of pursuing its activities. Second, however, the freedom 
of movement of capital is applicable. In order to define the concept of capital movement, the nomenclature provided by Directive $88 / 361$ has a relevant indicative value, even if the list is not exhaustive. Investment in real estate is included in this list, and, therefore, freedom of movement covers both ownership and management of such property. In this context, the fact that, under German domestic law, the tax exemption applies only to charitable entities which, as a matter of principle, have an unlimited tax liability in Germany puts non-resident comparable organizations at a disadvantageous position, which constitutes a restriction on the free movement of capital. In order to be justified, the difference in treatment between a foundation with unlimited tax liability and those with limited liability "must concern situations which are not objectively comparable, or be justified by overriding reasons in the general interest, such as the need to safeguard the coherence of the tax system or effective fiscal supervision." ${ }^{27}$ In addition, the difference in treatment must not go beyond what is necessary in order to attain the objective of the applicable legislation. ${ }^{28}$ The German government tried to justify the difference of treatment, notably, by arguing that a resident non-profit entity performs duties which usually would be a burden on the state budget, whereas the charitable activities performed by the foundation only concerned Italy and Switzerland. The ECJ did not follow that line of reasoning. In particular, the necessity of a link between the foundation and its activities was regarded as non-relevant. As a consequence, in the absence of a justification and overriding reasons of general interest, the ECJ found that the freedom of movement of capital had been infringed.

Having examined the scope of the rules on exemption from the perspective of the beneficiary, the ECJ then had to address the tax position from the point of view of a donor who was resident in an EU Member State and made a gift to a philanthropic entity sited in another EU state. In Persche, a German citizen had made a gift to a charitable organization in Portugal. The German tax authorities had disallowed the deduction, as the beneficiary did not meet German law requirements. ${ }^{29}$ The ECJ was being asked to give a preliminary ruling on the admissibility of such a refusal. First, the court stated, in essence, that, when a taxpayer requests a tax deduction in one Member State with respect to gifts made to established organizations of acknowledged general interest in another Member State, such gifts "come within the compass" of the provisions relating to the free movement of capital, even if they are made in kind in the form of common consumer goods. ${ }^{30}$ Second, the possibility of obtaining a deduction for tax purposes "can have a significant influence on the donor's attitude" so that the inability to deduct gifts to charitable bodies established in another Member State constitutes a restriction on the free movement of capital. ${ }^{31}$ Third, this restriction is not justified. While the states have discretion to define the interests of the general public that they wish to promote by granting tax benefits, they cannot deny the right to equal treatment of a gift to a charitable body in another Member State, promoting the same interests of the general public recognized by the first Member State, "solely on the grounds that it is not established in that Member State" 32 . The ECJ considered, however, that, according to the principle of proportionality, nothing prevents the tax authorities of the Member State to require the taxpayer wishing to obtain the deduction to provide relevant evidence. In addition, the tax authorities concerned may contact the authorities of the other Member State in order to obtain information that may be necessary on the basis of Directive $77 / 799$ on exchange of information. ${ }^{33}$ As a consequence, since Persche, gifts from a taxpayer of one Member State to an institution with a public purpose in another Member State are governed by the principle of the free movement of capital and therefore cannot be the subject to tax discrimination in the case where the recipient is a charitable entity established in another Member State promoting similar interests of the general public.

In the third case, the ECJ had to examine tax discrimination in the area of gift and inheritance tax. The case Missionswerk involved a bequest from a Belgian resident on her death to an 
association with a religious purpose in Germany. ${ }^{34}$ The Belgian tax authorities wanted to apply an $80 \%$ tax rate to the bequest, whereas the same bequest would have been taxed at a rate of $7 \%$ under domestic law. Once again, in keeping with its previous judgments, the ECJ held that the Belgian inheritance and gift rules were discriminatory. In order to reach that conclusion, the ECJ considered that a cross-border inheritance constitutes a movement of capital within the meaning of Art. 63 Treaty on the Functioning of the European Union (TFEU). Taxing an inheritance, whose beneficiary is a non-profit-making body, which has its center of operations in another Member State, in which the deceased neither actually resided nor worked, more heavily constitutes a restriction to the free movement of capital by reducing the value of that inheritance. ${ }^{35}$ Indeed, this rule is liable to make those cross-border capital movements less attractive by dissuading Belgian residents from naming as beneficiaries persons established in Member States in which those Belgian residents have not actually resided or worked. In addition, this restriction is not justified. The Belgium government tried to argue that Member States are entitled to require, for the purposes of granting certain tax benefits, a sufficiently close link between non-profit-making bodies and the activities in which they are engaged. In the present case, Belgium collectivity takes an advantage from that regulation. However, according to the EUCJ, the fact that a Member State may be discharged from some of its responsibilities does not allow that state to establish a difference of treatment with the motive that the bequest made in favor of organizations with a public purpose in another state cannot result to a budgetary compensation in the state of source. Indeed, according to the court, the necessity to prevent a reduction of tax resources is neither a motive mentioned in Art. 65 TFEU nor an overriding reason in the general interest justifying a restriction to Art. 65 TFEU. ${ }^{36}$ Therefore, the EUCJ, following its previous case law, considered the Belgium legislation discriminatory.

Finally, in Commission vs Austria, the EUCJ also confirmed that an Austrian tax rule, according to which deductions from tax are allowed solely for gifts to research and teaching institutions whose seats are in Austria, to the exclusion of gifts to comparable institutions established in other Member States of the EU or the EEA, is contrary to the free movement of capital, as guaranteed by Article 56 EC and Article 40 of the EEA Agreement. ${ }^{37}$ The Court, in its reasoning, also referred to the previous case, Laboratoires Fournier, of $2005 .{ }^{38}$ In the latter, while the ECJ held that the promotion of research and development may constitute a reason of overriding interest, the court nevertheless considered that national legislation reserving the benefit of a tax credit solely to research carried out in the Member State concerned was directly contrary to the objective of European Union policy in the field of research and technical development. In accordance with Article 163(2) EC, that policy aims in particular to remove the fiscal obstacles to cooperation in the field of research and cannot therefore be implemented by the promotion of research and development at the national level. The same is true of the tax rules concerning gifts at issue in the present case, insofar as the Republic of Austria relies on that objective to limit the deductibility of gifts to Austrian research establishments and universities. ${ }^{39}$ It is interesting to note that, according to the Court, since the provisions of Article 40 of the EEA Agreement have the same legal scope as the substantially identical provisions of Article $56 \mathrm{EC}$, the considerations of the case law on that provision may, in similar circumstances such as those of the present case, be transposed mutatis mutandis to Article 40 EEA.

\section{B Impact of EUCJ case law}

It follows that Member States have an obligation to treat domestic and foreign charitable entities in another Member States equally. However, even if the principle of non-discrimination has to be observed within the EU, there are still many difficulties for charitable entities and 
donors to "effectively exercise their fundamental freedoms." ${ }^{40}$ First, there is no global recognition of charitable entities. Indeed, as seen previously, the conditions of tax-exempt status are defined by the domestic law of the host state. Second, the charitable entity has to prove that it complies with the tax-exempt status conditions, as defined under the domestic law of the host state. ${ }^{41}$ Third, the state of the donor has to be able to properly verify that such conditions are met, which requires an effective and adequate exchange of information clause in a Directive or a multilateral or bilateral treaty.

The case law of the EUCJ, in the context of the freedom of movement, could have an impact in non-EU third countries, such as Switzerland. Indeed, Art. 63 TFEU prohibits restrictions on the free movement of capital not only between Member States but also between Member States and third states. Consequently, gifts or payments derived from EU Member States to a third country, such as Switzerland, could benefit from this case law. ${ }^{42}$ In the specific case of Switzerland, this is also justified by the fact that, even though Switzerland is not an EU Member State, it has adopted a European policy based on bilateral sectoral agreements. These agreements create broad, reciprocal access to markets and form the basis of close collaboration in several areas. As a consequence, in our view, attributions from an EU state towards non-EU countries should in principle be able to benefit from the case law developed by the EUCJ, following the Persche case. Following these cases, however, the EU state of residence of the donor should still be in a position to obtain relevant information from the state of the beneficiary. This condition should be met, to the extent that both states provide for an effective exchange of information, following the OECD standard of Art. 26 OECD Model DTC. This should notably be the case between Switzerland and an EU Member State, since the change of policy of Switzerland, as of 13 March 2009, in the area of exchange of information, to the extent of a DTC following the OECD standard, has been ratified between those countries. ${ }^{43}$

The question of whether a similar rule could also apply in the opposite direction, namely in the case of payments arising from a donor resident in a third country, such as Switzerland, in favor of a philanthropic institution sited in an EU state, is more delicate. In this context, an international agreement between the third country and the EU state providing for a freedom of movement of capital should exist. This should in particular be the case for EEA Member States. For third countries outside the EU or the EEA, it could be interesting to check whether a similar rule might be derived from the principle of non-discrimination under a tax treaty that incorporates a provision similar to Art. 24 of the OECD Model DTC with that EU Member State. ${ }^{44}$

\section{Proposal for a European Foundation}

Despite the case law mentioned previously, the situation is still not satisfactory for cross-border donations within Europe. First, some Member States still have not implemented the rules of non-discrimination and either tend to discriminate against foreign-based EU nonprofit entities compared to local ones or provide very complex rules and processes in order for a foreign-based non-profit organization to be viewed as comparable to a resident entity. ${ }^{45}$

On 8 February 2012, as a multilateral solution to this problem, the EU Commission presented a Proposal for a Council Regulation on the Statute for a European Foundation (FE) (hereafter FE Prop. Regs). ${ }^{46}$ This initiative intended to create a new European legal form which should facilitate the establishment and operation of foundations in the single market. It should allow "foundation to more efficiently channel private funds to public benefit purposes on a cross-border basis in the EU." ${ }^{47}$ The proposed Regulation would also include a chapter on the tax treatment of the FE, donors and beneficiaries. First, with respect to income and capital gain taxes, gift and inheritance taxes, property and land taxes, transfer taxes, registration taxes, stamp 
duties and similar taxes, the Member States where the FE has its registered office would have to apply the same tax treatment as applicable to public benefit-purpose entities established in that Member State (art. 49 FE Prop. Regs). Second, the same tax treatment applicable to donations made to public benefit-purpose entities established in the Member State where the donor is resident should apply to any natural or legal person donating to the FE (Art. 50 FE Prop. Regs.). Third, beneficiaries of the FE should be treated as if they were given by a public benefit purpose entity established in the Member State or residence of the beneficiary (Art. 51 Prop. Regs). It was apparently difficult to reach the required unanimous approval of Member States. ${ }^{48} \mathrm{~A}$ possibility to reach a consensus could have been to delete the tax chapter of this draft Directive. Finally, the proposal was withdrawn in March $2015 .{ }^{49}$

\section{Impact of double taxation conventions}

\section{A In general}

Non-profit organizations, as we have seen, may face complexities and even multiple taxation issues in cross-border payments. In addition, based on different domestic law rules, payments to foreign non-philanthropic entities could face adverse tax consequences, notably due to the absence of recognition by the host state of the tax-exempt status granted by a foreign state. DTCs could be used as tools to solve or alleviate or at least improve those issues. ${ }^{50}$ In order to achieve these goals, a DTC should be applicable to philanthropic entities, despite their taxexempt status (infra B.). In addition, specific treaty rules could either grant an exemption to income received by a non-profit entity resident in a contracting state (infra C.) or even offer a tax incentive, such as a deduction for cross-border gifts in favor of philanthropic entities sited in another contracting state (D.). Limitation on benefits (LOB) treaty rules, to the extent they are applicable, sometimes also grant qualifying status to non-profit entities (E.). DTCs could also ensure that cross-border gifts or inheritance will not be subject to multiple or burdensome tax (F.). Finally, an interesting possibility would be to rely on the non-discrimination provision of DTC to try to offer comparable tax treatment of payments to domestic and comparable nonprofit entities sited in another contracting state (G.).

\section{$B$ Residence of charitable entity}

The first issue is to ascertain that charitable entities may benefit from a DTC. It requires that these entities may be regarded as (i) persons, according to Art. 3 OECD Model DTC, which are (ii) resident in a contracting state, within the meaning of Art. 4 OECD Model DTC. According to the OECD Commentary, the term "person" should be interpreted broadly. A foundation or an association is notably considered a person. In order to be "resident," such an entity should meet the criteria to be fully taxable according to domestic law. It is, however, not important whether the state of residence makes use of the effective right to tax. ${ }^{51}$

The OECD Commentary confirms this position by stating that:

In many States, a person is considered liable to comprehensive taxation even if the Contracting State does not in fact impose tax. For example, pension funds, charities and other organizations may be exempted from tax, but they are exempt only if they meet all of the requirements for exemption specified in the tax laws. They are, thus, subject to the tax laws of a Contracting State. Furthermore, if they do not meet the 
standards specified, they are also required to pay tax. Most States would view such entities as residents for purposes of the Convention. ${ }^{52}$

Following this approach, Art. 4 OECD Model DTC offers a protection against so-called virtual double taxation and provides for a limit towards the other contracting state, even if the state of residence does not levy a tax. The U.S. Model DTC (2016) is even more precise in that it provides, in Art. 4, that the term "resident of a Contracting State" includes:

an organization that is established and maintained in that Contracting State exclusively for religious, charitable, scientific, artistic, cultural, or educational purposes; notwithstanding that all or part of its income or gains may be exempt from tax under the domestic law of that Contracting State. ${ }^{53}$

Many countries, such as Switzerland, follow this approach for charitable entities sited in their territory, despite tax-exempt status. As a consequence, notwithstanding the exemption of legal persons, which pursue public utility goals, these countries treat them as residents for tax purposes. ${ }^{54}$

According to the OECD Commentary, contracting states may solve the tax status of such entities in a specific provision of a DTC. ${ }^{55}$ Following this approach, specific DTCs, following the approach of the U.S. Model, entail a provision providing that exempt charitable entities are regarded as resident. This is the case, for example, of many treaties concluded by the United States, ${ }^{56}$ such as, inter alia, the U.S. treaties with the United Kingdom, Australia, Ireland and Switzerland. ${ }^{57}$ The United Kingdom also includes specific clauses in many DTCs granting residence to non-profit organizations established in one contracting state. ${ }^{58}$ Other states, however, consider tax exempt entities not resident for the purposes of DTCs. ${ }^{59}$

In order to continue to ensure the proper development of philanthropic activities, it should be recommended that states adopt the policy mentioned previously and simply confirm their positions that, as a matter of principle, charitable entities, despite their tax-exempt status, are in general regarded as resident for tax treaty purposes. Countries also have the possibility to confirm the application of tax treaties to non-profit entities in a mutual agreement procedure (MAP). Such agreements have already been concluded in practice. ${ }^{60}$

This would allow resident non-profit entities to claim the benefits of the allocation rules of the treaty, notably a reduced or nil withholding tax at source on any dividends, interests or royalties sourced in the other contracting state, as provided in provisions similar to Art. 10, 11, or 12 of the OECD Model of the applicable treaty.

\section{Exemption}

As resident entities, non-profit organizations could claim the benefit of tax treaties, to the extent they comply with the potential limitation on benefits rules, if applicable ${ }^{61}$. In general, most DTCs entail distributions rules for specific foreign source income, notably for dividend, interest, royalties and sometimes services that may still suffer a residual withholding tax at source.

A few treaties go even further than confirming a residence status to philanthropic entities by providing a general tax exemption from income sourced in another contracting state. ${ }^{62}$ These examples are, however, rare and exist mostly with some treaties concludes by the United 
States. ${ }^{63}$ As an interesting example, Art. 27 (Exempt Organizations) of the U.S.-Germany treaty provides that:

1. Notwithstanding the provisions of Article 28 (Limitations on benefits), a German company or organization operated exclusively for religious, charitable, scientific, educational, or public purposes shall be exempt from tax by the United States in respect of items of income, if and to the extent that:

a) such company or organization is exempt from tax in the Federal Republic of Germany, and

b) such company or organization would be exempt from tax in the United States in respect of such items of income if it were organized, and carried on all its activities, in the United States.

2. Notwithstanding the provisions of Article 28 (Limitations on benefits), a United States company or organization operated exclusively for religious, charitable, scientific, educational, or public purposes shall be exempt from tax by the Federal Republic of Germany in respect of items of income, if and to the extent that:

a) such company or organization is exempt from tax in the United States, and

b) such company or organization would be exempt from tax in the Federal Republic of Germany in respect of such items of income if it were organized, and carried on all its activities, in the Federal Republic of Germany.

In general, these provisions apply only to a non-profit organization resident in one contracting state that would also be exempt from tax in the other contracting state if it were organized and carried their activities in that state.

The advantage of such provisions is that they apply to all types of income and not only to dividends, interests or royalties. In addition, the exemption would go beyond the benefits of treaties with provisions similar to Art. 10, 11 or 12 of the OECD Model DTC in that it would grant a zero rate and not a reduced rate of tax at source, as the case may be.

In the case where a state uses the credit method for the avoidance of double taxation, the benefits of the tax exemption granted in another state, in the absence of a specific rule, would lead to a virtual double taxation. ${ }^{64}$ Indeed, the exemption granted in one contracting state would lead to the absence of a credit in the other contracting state, unless that state includes a rule that would take this situation into account. States under a credit system could therefore be recommended to include a specific exception to the credit method for non-profit entities exempt in other states to the extent that they would qualify as exempt entity if they were resident in the state imposing the credit.

\section{Deductions of cross-border gifts}

To the extent it is applicable, a DTC will then attribute, following the allocation rules, the right to tax income and, to the extent relevant, the assets of such entity between the contracting states. Under existing law, in principle, the allocation rules of a DTC focus on income (or profit) and, as the case may be, on capital (or wealth) but do not apply to the tax treatment of deductions. In particular, DTCs do not entail any specific rule applicable to cross-border deductions or allocations in favor of entities following philanthropic purposes. Tax treaties may, however, be used as promoting tools and could include an incentive for cross-border charitable 
giving in the form of a deduction, which is usually available to gifts to domestic non-profit entities in the host state. ${ }^{65}$

The Netherlands, admittedly in a fairly isolated case, and the United States, with some states that are tightly linked geographically, have included such clauses in their tax treaties. ${ }^{66}$ It seems that the inclusion of a provision on charitable donation is also part of the tax treaty policy of the Barbados. ${ }^{67}$ The possibility, under specific conditions, to deduct cross-border gifts does exist under the U.S.-Canada DTC (1980), the U.S.-Mexico DTC (1992) and the U.S.-Israel DTC (1995). ${ }^{68}$ The provisions of these DTCs providing for a charitable deduction do, however, limit the deduction of donations to the other contracting state from income derived from that particular state ${ }^{69}$ Another interesting example is given by Art. 22 of the Netherlands-Barbados treaty, ${ }^{70}$ which provides for the following rules for charitable contributions:

Contributions by a resident of a Contracting State to an organization constituting a charitable organization under the income tax laws of the other Contracting State shall be deductible for the purposes of computing the tax liability of that resident under the tax laws of the first-mentioned Contracting State under the same terms and conditions as are applicable to contributions to charitable organizations of the firstmentioned State where the competent authority of the first-mentioned State agrees that the organization qualifies as a charitable organization for the purposes of granting a deduction under its income tax laws.

In order to encourage cross-border philanthropic giving, countries would be well advised to insert clauses in their tax treaties that would allow for recognition of a deduction for gifts to entities that have an acknowledged public purpose under the same conditions as those of the donor's state of residence. We will, however, analyze further the potential implications of the principle of non-discrimination.

\section{E Limitation on benefits provisions}

Under the influence of the United States treaty policy, so-called "limitation of benefits" provisions have been implemented in many treaties. Following the OECD Base Erosion Profit Shifting (BEPS) program, the 2017 version of the OECD Model DTC includes a new Art. 29, which opens the possibility to negotiate a LOB clause in a DTC. This approach is based on a list of alternative tests, which have to be fulfilled in order to be able to claim the benefits of a DTC. A LOB clause aims at discouraging treaty shopping by giving the advantages of the treaty only to qualifying persons.

Without any specific clauses, non-profit resident entities have to verify that they meet at least one of those tests in order to qualify for the benefit of the treaty. However, some treaties do consider philanthropic entities, as such, qualifying persons under LOB clauses. ${ }^{71}$ For states that wish to include LOB clauses in their treaties, these types of specific qualifying provisions should provide for a simple and efficient mechanism to avoid a complex analysis of the LOB tests for philanthropic entities.

\section{F Exemption of gift and inheritance tax to cross-border non-profit entities under gift and inheritance tax treaties}

There are also a few DTCs in the area of inheritance tax and, rarely, in the field of gift tax. For instance, Switzerland has concluded only nine DTCs in the area of inheritance tax and no DTC 
for gift tax purposes. Again, and in the rare cases where such treaties do exist, they generally do not offer any specific tax treatment for cross-border inheritance or gifts in favor of philanthropic institutions. We have seen, however, that in the case of Switzerland, some cantons have concluded reciprocal agreements for gifts with religious, charitable or public utility purposes, but only with five states. However, the non-discrimination principle anchored in Art. 24 of the OECD Model for direct tax purposes, applies to "taxes of every kind and description." 72 The analysis of the impact of such a principle is thus relevant not only for direct but also inheritance and gift taxes.

There are, however, some rare treaty provisions that include rules which try to minimize the adverse tax consequences of cross-border payments for inheritance and gift tax purposes. Such treaties have been concluded mostly with the United States. ${ }^{73}$ For example, Art. 9 of the DTC between the United States and Denmark provides the following rules for charitable gifts and estate (reductions):

1. The transfer or deemed transfer of property to or for the use of a Contracting State or a political subdivision or local authority thereof, or to a corporation or organization of a Contracting State operated exclusively for religious, charitable, scientific, literary, or educational purposes, if such transfer is exempt from tax or taxed at a reduced rate in that state shall be treated by the other Contracting State as if such transfer or deemed transfer were made to a similar corporation or organization of that other State.

2. In the case of property which passes from a decedent

a) domiciled (within the meaning of Article 4 (Fiscal Domicile)) in Denmark to the spouse of such decedent, the United States shall, in computing its tax, allow the same marital deduction that would be allowed with respect to a decedent domiciled in the United States, and in such case the tax rates that would be applicable if the decedent had been domiciled in the United States shall apply. If the United States tax determined without regard to the preceding sentence is lower than that computed under the preceding sentence, the lower tax shall apply.

b) domiciled (within the meaning of Article 4 (Fiscal Domicile)) in the United States to the spouse of such decedent, Denmark shall, if the spouse so requests, compute its tax as if the provisions of Danish law regulating matrimonial property rights were applicable to such property.

Art. 10 of the DTC between the United States and France, with respect to taxes on estates, inheritances and gifts, provides the following rule for charitable exemptions and deductions:

(1) A transfer to a legal entity created or organized in a Contracting State shall be exempt from tax, or fully deductible from the gross value liable to tax, in the other Contracting State with respect to its taxes referred to in Article 2, provided the transfer would be eligible for such exemption or deduction if the legal entity had been created or organized in that other Contracting State.

(2) The provisions of paragraph (1) shall apply only if the legal entity: (a) Has a tax-exempt status in the first Contracting State by reason of which transfers to such legal entity are exempt or fully deductible; (b) Is organized and operated exclusively for religious, charitable, scientific, literary, educational or cultural 
purposes; and (c) Receives a substantial part of its support from contributions from the public or governmental funds.

(3) This Article shall not apply to transfers to a Contracting State or a political or administrative subdivision thereof unless specifically limited to a purpose described in paragraph (2)(b).

In general, these clauses tend to offer equivalent rules for domestic and foreign entities in the treaty partner, subject, however, to specific conditions. In other words, a contracting state should treat a transfer to a foreign charitable entity in the other contracting state at a reduced or zero rate, as if such transfer were made to a similar organization in the state of donor or deceased. ${ }^{74}$

\section{G The non-discrimination principle}

\section{In general: Art. 24 par. 1 OECD model}

DTCs in the area of direct taxes do generally provide for a non-discrimination clause corresponding to Art. 24 par. 1 OECD Model DTC, according to which:

National of a Contracting State cannot be subject in the other Contracting state to any taxation or any requirement connected therewith, which is other or more burdensome than the taxation and connected requirements to which nationals of that other State in the same circumstances, in particular with respect to residence, are or may be subjected.

This rule applies to "taxes of every kind and description" 75 and therefore also to taxes falling outside the scope of the treaty in question, such as inheritance or gift taxes. ${ }^{76}$ In actual terms, the non-discrimination principle means that a tax applied to nationals and foreigners in the same circumstances,

must be in the same form, as regards both the basis of charge and the method of assessment, its rate must be the same and, finally, the formalities connected with the taxation (returns, payment, prescribed times, etc.) should not be more onerous for foreigners than for nationals. ${ }^{77}$

In the situation in question, partial or total exemption means a rate reduction that would be refused to foreign institutions due to their place of incorporation.

Consequently, the compatibility with such a non-discrimination clause of a reduced exemption or a more burdensome taxation of cross-border payments for philanthropic purposes in comparison to the potential more favorable tax regime applicable for comparable domestic charitable payments may be questioned. ${ }^{78}$

However, the non-discrimination clause of current DTCs, based on the OECD Model, still relies on the criteria of the nationality. In other words, and contrary to the case law of the EUCJ mentioned previously, Art. 24 par. 1 OECD Model only protects against overt and direct discrimination based on nationality. ${ }^{79}$ In this respect, the principle of non-discrimination is different in scope from the EU principle, which also protects against so-called "hidden" and indirect discriminations, which, while not openly based on the concept of nationality, are in effect essentially targeting nationals. ${ }^{80}$ As a consequence, until now, DTCs following Art. 24 
par. 1 OECD Model have had limited impact, notably for individuals, because most states apply domestic tax rules, which are based on residence and not on nationality. ${ }^{81}$

The same is also true, in general, for philanthropic institutions, which are usually treated differently according to the criteria of residence, that is depending on their seat. In addition, the historical interpretation of Art. 24 par. 1 OECD Model tends to confirm that the initiators of this provision did not intend to offer the same tax advantages as comparable local entities to non-resident entities with public utility purposes. ${ }^{82}$ The OECD Commentary follows the same line of reasoning. Indeed, it provides that Art. 24 par. 1 OCDE Model should not be interpreted as compelling contracting states, which offer certain tax privileges to private nonprofit institutions, to extend those privileges to similar institutions which pursue non-profit activities. ${ }^{83}$ At this stage, to the best of our knowledge, the jurisprudence does not seem to have interpreted Art. 24 OECD Model differently. In our view, only an evolutive interpretation of Art. 24 OECD Model, following the case law of the EUCJ, which would opt for a protection against hidden or indirect discrimination based on nationality, could justify such a broadening of the scope of the rule against non-discrimination.

As a consequence, even if in practice the differences of treatment between comparable resident and non-resident philanthropic entities may constitute "hidden" or indirect discrimination, because the exemption or the tax deduction would only apply to resident philanthropic entities, this discrimination is not overtly based on nationality. The leading and current interpretation of Art. 24 par. 1 of the OCDE Model tends therefore not to compel the state of residence to extend the same privileges offered to resident philanthropic entities to similar entities sited abroad.

\section{Art. 24 par. 4 OECD model}

Art. 24 par. 4 of the OECD Model DTC may, however, offer a broader scope of application. According to 24 par. 4 OECD Model DTC, interests, royalties and "other disbursements" paid by an enterprise of a contracting state to a resident of the other contracting state must, for the purpose of determining the taxable profits of such enterprise, be deductible under the same conditions as if they had been paid to a resident of the first-mentioned state. This time, such a rule does not allow for indirect discrimination based on residence, to the extent that this clause targets (non)residence of the person benefiting from the payment and not of the person who challenges the non-discrimination. ${ }^{84}$ As a consequence, it should be analyzed whether this different perspective of the principle of non-discrimination may challenge the differences of treatment between domestic and cross-border philanthropic payments in favor of similar entities. In particular, we could wonder whether the refusal of a deduction for gifts towards philanthropic entities resident in a state other than the state of the donor would not be contrary to a provision of a DTC, including a rule similar to Art. 24 par. 4 OECD Model DTC.

The answer requires a careful analysis. First, it should be questioned whether "gifts" or other liberalities fall into the concept of "other disbursements" mentioned in this provision. According to commentators, contributions - such as gifts - which do not represent a counterpart are not governed by the OECD norm. Indeed, such a provision tends to apply to interest, royalties and other expenses which represent a remuneration for a transaction (services) or an investment (capital). ${ }^{85}$ Such interpretation is, however, not the only conceivable one. Indeed, the OCDE Commentary admits that this provision could also include payments to a pension fund by the employer. ${ }^{86}$ In any event, such a broad interpretation of the concept of "other disbursements" to gifts is undoubtedly disputable. In addition, this rule only applies to expenses paid by an enterprise. According to Art. 3 par. 1 lit. c OECD Model DTC, this term refers to the "carrying on 
of any business." The term "business" includes the performance of professional services and of other activities of independent nature. ${ }^{87}$ According to commentators, this concept is difficult to assess and rather "ambiguous." ${ }^{88}$ In addition, the question of whether an activity is performed in an enterprise or is deemed to constitute in itself an enterprise has always been interpreted according to the provisions of the domestic law of the contracting states.$^{89}$ It follows that at least the deduction from an individual, acting in a non-independent activity, in favor of a nonresident entity following philanthropic purposes, following a similar treatment in domestic law, could not benefit from this provision.

As a consequence, a potential violation of the non-discrimination principle could exist in the case of refusal of deductions in favor of non-resident public utility institutions, which are, however, allowed for similar domestic organizations but only under narrow limits. These deductions should at least be claimed by legal persons or individuals acting in an independent capacity that should be characterized as enterprises and only to the extent that we may characterize such gifts as "other disbursements" within the meaning of Art. 24 par. 4 OECD Model. In this framework, cross-border payments could be deductible under the same conditions as gifts in favor of residents in the state of the payer. ${ }^{90}$ In this case, the amount of deduction, the timing and all other conditions should be the same. ${ }^{91}$

\section{Conclusion and recommendations}

Our chapter has shown that DTCs may indeed offer interesting solutions in order to solve, or at least alleviate, the potential tax burdens of cross-border charitable giving. This possibility should, in our view, be developed further because, apart from the EU, "there is little tax support provided by counties for cross-border giving." ${ }^{.2}$ In some rare cases, DTCs may even be used as tax incentives to promote transnational giving by offering a deduction, under specific conditions, which would correspond to domestic gifts or payments to local non-profit entities. However, the practice is not well established, and there are in fact only a very few treaties that include specific clauses that favor cross-border charitable giving, mostly some United States and United Kingdom treaties, and, in the case of Barbados, part of a general policy. The author would recommend clarifying the position of states with regard to the application of DTCs in favor of non-profit entities and the application of similar rules between domestic gifts to philanthropic organizations and foreign comparable institutions in contracting states. This could be achieved by implementing the following recommendations.

First, states should be encouraged to clarify their position on the application of DTCs to charitable entities. Following the majority view described previously, states should admit that, despite their tax-exempt status, non-profit entities are recognized as resident for DTC purposes. Perhaps a clarification of the OECD Commentary on Art. 4 could solve this controversy. States that do not wish to accept this interpretation should then at least include specific rules in their treaties that confirm this point. This would allow philanthropic organizations to claim the benefits of the allocation rules of a DTC, including the reduced withholding treaty rates for dividends, interests or royalties sourced in the other contracting state.

Second, contracting states, in order to create an incentive for philanthropic payments, could be encouraged to include in their DTCs a specific clause which would allow for the recognition of the deductibility of gifts to entities with public utility purposes, under the same conditions as philanthropic entities, seated in the place of residence of the payer. In this respect, Art. 22 of the DTC between Holland and Barbados of 2006, which provides for a deduction of gifts to a charitable entity in the other contracting state under the same conditions as gifts to entities recognized as such in the state of residence of the donor, could serve as a reference. 
Third, a new treaty rule could be introduced which would provide for a full exemption of foreign source income received by a philanthropic entity resident in a contracting states. Such provisions do already exist but only in rare cases. In general, they apply only to non-profit organizations resident in one contracting state that would also be exempted from tax in the other contracting state if they were organized and carried out their activities in that state. This rule applies to all types of income and not only to dividends, interests or royalties. In addition, the exemption would go beyond the benefits of treaties with provisions similar to Art. 10, 11 or 12 of the OECD Model DTC in that it would grant a zero rate and not a reduced rate of tax at the source, as the case may be.

Fourth, provisions could also be introduced in tax treaties in order to avoid multiple or adverse tax consequences of cross-border payments for inheritance and gift tax purposes. The recommendation, in order to have some impact, would require a broad change of policy among states and the conclusion of many more DTCs in the area of inheritance and gift taxes. In this respect, a provision similar to Art. 9 of the DTC between the United States and Denmark in the area of inheritance and gifts tax could serve a starting point of reference.

Fifth, under current law, DTCs based on the OECD Model do not offer a similar protection against non-discrimination for cross-border philanthropic payments as EU case law. Only an evolutive interpretation of Art. 24 par. 1 of the OCDE Model, which would go beyond the criteria of nationality, could broaden the scope of this principle. The current position, as confirmed by the OECD Commentary, does not seem to allow following the same line as the case law of the EUCJ. Furthermore, the non-discrimination principle applicable to "other disbursements," as governed by Art. 24 par. 2 OECD Model, does not seem under current law to undoubtedly apply to philanthropic gifts, even if sound arguments could be made, at least in the case of gifts or charitable payments from enterprises (including legal entities). As a consequence, the interpretation of the principle of non-discrimination in a DTC should be broadened to require a similar treatment of comparable non-profit entities in resident and non-resident states. While it appears difficult to adopt this rule from a political standpoint, a first step in this direction could be to clarify the interpretation of the concept of "other disbursements" in Art. 24 par. 4 OECD Model to include payments for philanthropic purposes.

Sixth, and in the long term, a more global solution, such as a multilateral approach, could be proposed. In this context, a mechanism similar to the multilateral treaty implemented in the context of the OECD BEPS program ${ }^{93}$ in order to incorporate treaty modification rules recommended by the BEPS Action plan could serve as a model. Indeed, in this context, a multilateral instrument (a so-called MLI) entered into force on 1 July 2018 in order to modify DTCs which are covered by the MLI, under a complex mechanism of acceptance by the states party to the MLI. The purpose of this multilateral instrument is clearly different in that it intends to include in DTCs various rules against aggressive tax planning of multinational enterprises and against double non-taxation. In the future, in any event, this type of multilateral mechanism is, however, an interesting model also for philanthropy because it allows modification, upon ratification, of all covered tax treaties. We could therefore also imagine introducing rules favorable to cross-border philanthropic payments within a multilateral mechanism similar to or inspired by the MLI. ${ }^{94}$

However, even if the principle of non-discrimination towards non-resident public purpose entities would more generally apply, the problem would not be completely solved. Indeed, as the impact of the tax law of the EUCJ has demonstrated previously, complexities or discriminating approaches among states could still exist and qualify as restrictions on the free movement of cross-border charitable payments. In this respect, multilateral solutions, such as the implementation of the EU FE, represent an interesting approach, which appears, however, 
difficult to implement. An alternative would be at least to try to find a consensus, for example, at the OECD level, on a recommendation (soft law) which would offer basic elements on the acceptance of a similar treatment of payments to domestic and foreign comparable public purpose entities. In this respect, some basic elements on the conditions of comparability should be designed. Common factors should be defined on: (i) a definition of the public non-profit purposes qualifying for the similar tax treatment and (ii) the essential elements of an adequate supervision mechanism, which could be viewed as acceptable and equivalent to the supervision rules applicable in the host state.

Finally, it appears that, in order to ensure that the benefits of a treaty are fully granted to non-profit entities, the mains issue is to include a rule which recognizes, under clear conditions, the equivalence of non-resident entities and similar domestic entities. ${ }^{95}$ In order to verify that this condition is met, various solutions have been introduced by some states. This issue is crucial and is the key to fostering the development of cross-border philanthropic payments without tax infringements. The case law of the EUCJ, mentioned previously, also confirms the necessity to compare non-profit domestic entities and foreign organizations with similar charitable purposes sited in another EU state. A specific treaty provision could also be introduced in this respect and provide for the key binding conditions of such recognition. It is also essential to ensure that the qualifying philanthropy entity does pursue a legitimate and effective activity for a non-profit purpose, which could be more precisely defined in a relevant treaty provision. Furthermore, the issue will be to safeguard the ultimate proper destination of the funds for charitable purposes, which requires extensive due-diligence rules and an adequate supervision mechanism. ${ }^{96}$ To that end, the exponential development of the network of rules of international administrative assistance in tax matters, as of March 2009, has opened broad possibilities for states to verify all foreseeable relevant information, including financial data. ${ }^{97}$ The development of anti-moneylaundering rules, and the corresponding due diligence requirements, should also help to bring more certainty to the effective and adequate use of funds transferred for charitable purposes.

\section{Notes}

1 For a comprehensive report on the tax treatment of philanthropy across 40 OECD members and participating countries, see recently, OECD, Taxation and Philanthropy, OECD Tax Policy Studies, No 27, Paris 2020 .

2 In this chapter, we will use the term philanthropic or non-profit entities or charitable organizations as synonyms.

3 The tax treatment of charitable trusts would require a further analysis, which goes beyond the scope of this chapter, since most states do not recognize trusts as such as legal entities.

4 See OECD, Philanthropy and Taxation, op. cit. 2020, pp. $41 \mathrm{ff}$.

5 See Art. 23 al. 1 lit. f of the Federal Harmonization Tax Law (FHTL); Art. 56 lit. g of the Federal Direct Tax Law (FDTL).

6 Under Swiss law, possibilities to exempt philanthropic entitles have been extended by a change of the law as of 1 January 2018 for legal persons pursuing "ideal goals" to the extent their profits are below CHF 20 000, under federal rules, and under a threshold applicable under cantonal law (see Art. 66a FDTL; 26a FHTL).

7 See, Federal Tax Administration (FTA), Circular N. 12, 8 July 1994, p. 3 (hereafter Circular FTA, par. 12).

8 See notably, "Swiss Tax Conference" (STC), "Exonération des personnes morales qui poursuivent des buts de service public, d'utilité publique ou des buts cultuels/Déductibilité des libéralités", 18 January 2008, pp. 38 ff (hereafter Circular STC 2008); see also Circular FTA no 12, 8 July 1994; X. Oberson, Droit fiscal Suisse, 5th ed., Basel, Helbing \& Lichtenhahn 2021, pp. 254 ff. 
9 See Sec. 501 (c) and (d) IRC; Sec 170 (e) to (o) IRC; S. Heidenbauer, B. Hemels, W. Muehlmann, M. Stewart, O. Thommes and T. Tukic, Cross-Border Charitable Giving and Its Tax Limitations, Bulletin for International Taxation, November 2013, p. 612.

10 See OECD, Philanthropy and Taxation, op. cit. 2020, p. 75 ff.

11 See Heidenbauer/Hemels/Muehlmann/Stewart/Thommes/Tukic, op. cit. 2013, p. 611; I. Koel, How Will International Philanthropy Be Freed from Landlocked Tax Barriers, European Taxation, September 2010, p. 409; recently, R. Buijze, Tackling the International Tax Barriers to Cross-Border Charitable Giving, IBFD, Amsterdam 2019, pp 72 ff.

$12 \mathrm{X}$. Oberson, The Taxation of Philanthropy in Switzerland: Current Status and suggestions for improvement, IBFD Bulletin for International Taxation 2015, p. 237.

13 Heidenbauer/Hemels/Muehlmann/Stewart/Thommes/Tukic, op. cit. 2013, p. 612.

14 Heidenbauer/Hemels/Muehlmann/Stewart/Thommes/Tukic, op. cit. 2013, p. 616.

15 B. Gouthière, Les impôts dans les affaires internationales, 10th ed., Paris, 2014, n. 49020, p. 706.

16 See www.transnationalgiving.eu.

17 Heidenbauer/Hemels/Muehlmann/Stewart/Thommes/Tukic, op. cit. 2013, p. 624.

18 For a general overview on the disparities of the domestic tax rules on cross-border inheritance and gifts, see J.-E. Navez, La fiscalité des successions et des donations internationales, Bruylant, Bruxelles, 2011, pp. 75 ff.

19 See OECD, Report of the OECD Committee on Fiscal Affairs 1982: Model Double Taxation Convention on Estates and Inheritances and on Gifts.

20 Navez, op. cit. 2011, p. 13.

21 In a nutshell, all Swiss cantons, to the exception of Schwyz and, more recently, Obwald, do levy an inheritance and gift tax. Lucerne, however, does not levy any gift tax.

22 See Art. 6 par. 2 of the Geneva cantonal tax law on inheritance tax; Art. 28 par. 2 of the Geneva cantonal tax law on registration duties (including gift taxes).

23 STC, “Informations fiscales, Les impôts sur les successions et les donations”, December 2016, p. 19.

24 Nowadays, 23 cantons have concluded international agreements on charitable gifts in the area of gift and inheritance tax, but only with France, Germany, Israel and Lichtenstein.

25 See European Foundation Centre, Taxation of Cross-Border philanthropy in Europe after Persche and Stauffer, 2014 (https://efc.issuelab.org/resources/18545/18545.pdf); B. Merkt and E. Zysset, Cross-Border donations, STEP Journal, May 2009, p. 33 ss. (https://www.step.org/step-journal/ step-journal-may-2009/cross-border-donations).

26 Case Centro di Musicologia Walter Stauffer v. Finanzamt München für Körperschaften, ECJ C-386/04, of 14 September 2006 (hereafter Stauffer case).

27 Stauffer case, op. cit. par. 32 .

28 Id.

29 Case Persche v. Finanzamt Lüdenscheid, ECJ C-318/2007, of 27 January 2009 (hereafter Persche case).

30 Art. 56 TFEU.

31 Persche case, par. $38 \mathrm{~s}$.

32 Persche case, par. 49.

33 Persche case, par. 61.

34 Case Missionswerk Werner Heukelbach v. Belgien, ECJ C-25/2010, of 10 February 2011 (hereafter Missionswerk case).

35 Case Missionswerk, par. 24.

36 Point 31; see also Persche case, par. 46.

37 Case Commission vs. Austria, EUCJ C-10/2010, of 16 June 2011 (hereafter case Commission vs. Austria).

38 Case Laboratoires Fournier, ECJ C-39/2004, of 10 March 2005.

39 Case Commission vs. Austria, par. 37.

40 Heidenbauer/Hemels/Muehlmann/Stewart/Thommes/Tukic, op. cit. 2013, p. 618; Buijze, op. cit. 2019, p. 305

41 See Heidenbauer/Hemels/Muehlmann/Stewart/Thommes/Tukic, op. cit. 2013, p. 618, who state that in the case of EU-wide projects, there are 28 comparability tests.

42 Oberson, op. cit. 2015, p. 237.

$43 \mathrm{X}$. Oberson, L'imposition des prestations philanthropiques transfrontalières - L'apport potentiel des normes de droit fiscal international, notamment des conventions de double imposition, in: Liber amicorum pour Henry Peter, Geneva/Zurich/Basel 2019, p. 567. 


\section{Cross-border philanthropic payments}

44 See infra IV. G.

45 Philanthropy Advocacy, Comments on EC Roadmap: Action plan to fight tax evasion and make taxation simple and easy, 31 March 2020.

$46 \operatorname{COM}(2012) 35$ final.

47 EU Commission, Proposed FE Regulation, n. 1.2.

48 Heidenbauer/Hemels/Muehlmann/Stewart/Thommes/Tukic, op. cit. 2013, p. 623.

49 Buijze, op. cit. 2019, p. 146.

50 Oberson, op. cit. 2019, pp. 557 ff; in the same vein, Buijze, op. cit. 2019, pp. 294 ff, 333, has also recently recognized the potential of DTCs for such goals but with many limitations.

51 M. Zweifel Martin and S. Hunziker, in: M. Zweifel, M. Beusch and R. Matteotti, Kommentar zum internationalen Steuerrecht, Basel, Helbing \& Lichtenhahn, 2015, n. 15 ad Art 4 OECD-MA.

52 OECD Commentary to Model DTC, n. 8.11 ad art. 4.

53 See Art. 4 (2) (b) of the U.S. Model DTC (version 2016).

54 Oberson, op. cit. 2014, n. 360, p. 115.

55 See, for instance, Art. 4 (1) (c) [ii] DTT with the United States.

56 Koel, op. cit. 2010, p. 24.

57 See, inter alia, Art. 4 (3) (c) of the U.S.-UK treaty; Art. 4 (1) (a) U.S.-Australia treaty, Art. 4 (1) (c) U.S.-Irish treaty; Art. 4 (1) (c) (ii) of the U.S.-Swiss treaty.

58 See inter alia, Art. 4 (5) (b) of the UK-Belgium treaty; Art. 4 (1) (c) of the UK-Japan treaty; Art. 4 (2) (b) of the UK-Norway treaty; Art. 4 (2) (b) of the UK-Holland treaty; par. 1 (b) of the Protocol to the UK-Swiss treaty; Art. 4 (2) (c) of the UK-UAT treaty.

59 Zweifel/Hunziker, op. cit., 2015, n. 15 ad Art. 4 OECD-MA

60 See Th. Ecker, Taxation of Non-Profit Organizations with Multinational Activities - The Stauffer Aftermath and Tax Treaties, Intertax 2007, pp. $450 \mathrm{ff}, 458$, quoting the examples of MAP concluded by Austria with Luxembourg, Germany and the United Kingdom.

61 See infra E.

62 See, for example, Art. 27 of the U.S.-Germany treaty; Art. 36 of the U.S.-Holland treaty; Art. 15A of the U.S.-Israel treaty; Art. XXI of the U.S.-Canada treaty.

63 Koel, op. cit. 2010, p. 31; for an analysis of these provision, see M. Cerny and M. McKinnon, The Globalization of Philanthropy: International Charitable Giving in the Twenty-First Century, 45 Real Property, Trust and Estate Law Journal 2020, pp. 10 ss.

64 Koel, op. cit. 2010, p. 356.

65 See also, Heidenbauer/Hemels/Muehlmann/Stewart/Thommes/Tukic, op. cit. 2013, p. 620; OECD, Philanthropy and Taxation, op. cit. 2020, pp. $112 \mathrm{ff}$.

66 Koel, op. cit. 2010, p. 34; Heidenbauer/Hemels/Muehlmann/Stewart/Thommes/Tukic, op. cit. 2013, p. 620; Buijze, op. cit. 2019, p. 131.

67 Heidenbauer/Hemels/Muehlmann/Stewart/Thommes/Tukic, op. cit. 2013, p. 620.

68 See OECD, Philanthropy and Taxation, op. cit. 2020, pp. 112 ff.

69 Buijze, op. cit. 2019, p. 133.

70 See Convention between the Kingdom of the Netherlands and Barbados for the avoidance of double taxation ant the prevention of fiscal evasion with respect to taxes on income, 26 November 2006; see also Heidenbauer/Hemels/Muehlmann/Stewart/Thommes/Tukic, op. cit. 2013, p. 620.

71 See, for example, Art. 16 (g) of the U.S.-Austrian treaty; Art. 18 (g) of the U.S.-Canada treaty; Art. 16 (f) of the U.S.-Finland treaty; Art. 17 (e) of the U.S.-Mexico treaty.

72 Art. 24 par. 6 OECD Model DTC

73 See Koel, op. cit. 2010, pp. 36 ff (citing five U.S. treaties); see Milton/McKinnon, op. cit. 2020, pp. 10 ff (analyzing four U.S. treaties).

74 See, for example, Art. 9 (1) of U.S.-Denmark treaty, Koel, op. cit. 2010, p. 36.

75 See Art. 24 par. 6 OECD Model DTC.

76 Oberson, op. cit. 2014, p. 282.

77 OECD Commentary, n. 15 ad Art. 24.

78 Oberson, op. cit. 2015, p. 238.

79 A. Rust, in: E. Reimer and A Rust (ed.), Klaus Vogel on Double Taxation Convention, 4e ed., Kluwer, The Netherlands, 2015, n. 26 ad art. 24.

80 Oberson, op. cit. 2014, p. 283; Rust, op. cit. 2015 , n. 14 ad art. 24.

81 Rust, op. cit. 2015 , n. 26 ad art. 24. 
82 K. van Raad and C. Landim, in: R. Danon, D. Gutmann, X. Oberson and P. Pistone (ed.), Commentaire du Modèle de Convention fiscale OCDE concernant le revenu et la fortune, Helbing \& Lichtenhahn, Editions Françis Lefebvre, Basle 2014, n. 62 ad art. 24.

83 OECD Commentary, n. 11 ad Art. 24.

84 Van Raad/Landim, op. cit. 2014, n. 97 ad Art. 24.

85 Rust, op. cit. 2015 , n. 95 ad Art. 24.

86 OECD Commentary, n. 37 ad Art. 18; Rust, op. cit. 2015, n. 95 ad Art. 24.

87 Art. 3 par. 1 lit. h OECD Model.

88 D. Gutmann and A. Lareau, in: Danon/Gutmann/Oberson/Pistone (ed.), op. cit. 2014, n. 29 ad Art. 24.

89 OECD Commentary, n. 4 ad art. 3.

90 Oberson, op. cit. 2019, pp. 557 ff.

91 Rust, op. cit. 2015, n. 99 ad Art. 24.

92 See OECD, Philanthropy and Taxation, op. cit. 2020, p. 131.

93 See, notably, OECD/G20, Base erosion and profit shifting (BEPS), Action 15, A multilateral instrument (MLI) to implement tax treaty related measures to prevent BEPS - Final Report 2015. The MLI has entered into force on 1 July 2018 and already covers more than 100 jurisdictions.

94 Oberson, op. cit. 2019, p. 572.

95 In the same vein, Koel, op. cit. 2010, p. 360.

96 Koel, op. cit. 2010, pp. 368 ff.

97 See X. Oberson, International Exchange of Information in Tax Matters - Towards Global Transparency, 2nd ed., United-Kingdom and United States, Elgar Tax Law and Practice, Cheltenham, UK, Northampton, USA, 2018, pp. 15 ff. 